III. Construction of a new imaginary of the city and public space: Saraus movement, mobility and religion

\title{
What happens between the roça and the urban periphery? \\ Some questions about movement
}

\author{
Luiz Felipe Rocha Benites' \\ 'Universidade Federal Rural do Rio de Janeiro, Instituto Multidisciplinar, Departamento de História, \\ Nova Iguaçu/RJ, Brasil
}

\begin{abstract}
This article explores the idea of movement through an analysis of the flows between rural and urban areas, more specifically between small farms (roças) and the peripheries of big cities. I turn to my own ethnographic research on rural and riverside communities in the north of Minas Gerais, as well as ethnographies produced on populations in the Cerrado Mineiro, in order to question the primacy of movement in the definitions of the city and to extend the notion through an approach that incorporates the relations between persons and things circulating in both these social spaces.
\end{abstract}

Keywords: Movement, peripheries, small-scale farming, rural-urban flows. 


\section{O que há entre a roça e a periferia?}

\section{Algumas questões sobre movimento}

\section{Resumo}

Este artigo busca problematizar a ideia de movimento a partir do trânsito entre os universos rurais e urbanos, mais especificamente entre a roça e as periferias das grandes metrópoles. Para tanto busco no meu material etnográfico sobre comunidades rurais e ribeirinhas no norte de Minas Gerais, bem como em etnografias realizadas no Cerrado Mineiro, instrumentos para por em questão a exclusividade do movimento como definidor da cidade e estendê-lo para uma abordagem que incorpore as relações entre pessoas e coisas que circulam pelos dois espaços sociais.

Palavras-chave: Movimento, periferia, roça, fluxo rural-urbano 


\title{
What happens between the roça and the urban periphery?
}

\section{Some questions about movement}

\author{
Luiz Felipe Rocha Benites
}

\section{Ethnographic preamble}

Afternoon is drifting into evening as I return to the house where I am lodged in Gerais Velho, a quilombola community in the small municipality of Ubaí, in the north of Minas Gerais, following a conversation with an interlocutor. On the way I cross paths with two lads from the community. As I greet them, I note that they are carrying hoes and that one of them has a mobile phone playing a song by Racionais MC's, a well-known rap group from the outskirts of São Paulo and widely popular throughout Brazil. The mobile phone signal was poor in the locality, save for some points on higher ground and a few homes equipped with special antennae to boost the signal. But this mattered little to the young people from this rural black community. The more recent models, purchased in São Paulo, were not only desired as status symbols, they were also a means of sharing the musical styles most enjoyed by them: forró and rap. The association of rap's image with the urban outskirts of different cities across the planet does not erase the fact that appropriation takes place far beyond these spaces. In this case, the taste for rap is just one elements connecting rural areas to the urban periphery in a scenario where people circulate people between and through the two spaces.

\section{Beginning the conversation}

The idea of this article is to produce a small analytic shift in approach and explore some of its implications: what happens when we take the viewpoint of those people who live in rural areas, but frequently transit between these areas and the city, as a basis for reflecting on urban peripheries, the city itself and the movement that tends to be associated with the urban world? The exercise proposed here sets out from an ethnographic observation: the inhabitants of two black rural communities in the northern region of Minas Gerais where I conducted my research, Ribanceira and Gerais Velho, take the practice of moving to large urban centres, especially Brasilia and São Paulo, as an important reference point in the constitution of local social life. In these displacements, an intense flow of exchanges and appropriations is established, historically explored by the social sciences as a question of the impact of the urban world on rural ways of life. Undoubtedly, the unidirectionality of this process has already been relativized and further research has provided an insight into the emergence of new ruralities (Carneiro 1998). What I propose here, though, is to contribute to problematizing the circulation of people and things outside the analytic frameworks of migration and the difference in scales between rural and urban collectives.

The people living in Ribanceira and Gerais Velho are described, including by themselves, as inhabitants of the roça. Originally referring to land cleared of forest or scrubland for plantation, the latter is a native category readily encountered in diverse Brazilian rural contexts. As will become clear from the material discussed below, my interlocuters refer to the roça as a place (rural area), a labour activity (agriculture and livestock breeding) and a condition (being 'from the roça' means to have a social origin and 
habits related to the rural world). As a concept that encompasses the ideas of place, labour and condition, the roça also functions as a parameter capable of situating other spaces (urban, fluvial, etc.), activities (work in charcoal kilns, fishing, etc.) or sociabilities (chats, visits, festivals, etc.). Fishing is an activity that does not exclude work in the roça, especially in Ribanceira where it is practiced conjointly. Neither the temporary work in charcoal kilns nor even long-term work in the city seem to erode the feeling of territorial and identificatory belonging linked to the roça.

On the other hand, while the category of roça has a deep connection to the ways in which my interlocuters problematize labour, what also clearly emerges from these formulations is a dimension of freedom associated with the control over labour activities that extends the meaning of roça to life outside of work, as I shall demonstrate later. It includes the practice of visits for prosear, chatting, ${ }^{1}$ the unregulated consumption of pinga and other situations, such as the frequent local festivals, the folias de reis, etc., which interrupt the work cycles and mobilize communities in activities of intense enjoyment. Hence, in the contet studied, roça constitutes a concept that is not reducible to the idea of farm.

The motivation to explore the rural-urban movement comes from a text by Michel Agier (2015:492) where he argues that the "...impulse towards a virtual centrality, embodied by the vital heart and identity of the city, simultaneously insatiable desire and infinite movement of the frontier to the centre, is the motor of urban action." The context in which this idea is formulated is made is an interpretation made by Henri Lefebvre, and later picked up by David Harvey, of the 1872 Paris commune as an event that was less about a working class uprising and more an urban struggle. Agier cites this interpretation in support of his proposal to situate what he calls city-making, that is "....an endless, continuous process without finality" in which "movement is essential to this conception of the city as a permanent construction. One of its declinations is displacement." Hence, "movement towards the centre from the peripheries and suburbs or the 'poverty zones' is a displacement and a spatial conquest" (idem: 491).

Agier's viewpoint is, without doubt, a rich form of apprehending the relations constituting the urbe. However, since I subscribe to the idea of a primacy of movement evoked by Tim Ingold (2011: xii), I think that a danger lurks in heuristically limiting our idea of movement to the urban circuit, or likewise in taking centre and periphery as substantive rather than relational entities. Consequently, I wish to bring the circulation of persons and things in themselves to the centre of analysis, leaving the departure and arrival points of these movements at the outer edges of the present reflection. Conferring centrality to movement, rather than the poles between which it occurs, allows us to think about mobility from both extensive and intensive perspectives, irrespective of the scale from which we approach the topic. In this way, we can affirm movement not only as the displacement or mobility between points or places, but also as a virtual intensity. This enables us to extend the idea that the city is made by movement to the analysis of any other topos, as well as approach movements in their intensive quality, perceiving what they mobilize within people.

\footnotetext{
1 A local term that designates the activity of conversing. Prosear, dar or ter uma prosa, is a practice so appreciated and important in the everyday life of the two communities that there exists an expression, prosa-ruim, 'bad chat,' for disagreeable or annoying people. There is a relation of identity between the characterization of the person and the quality of their conversation. A prosa-ruim individual is someone whose conversation, in their form of expression and/or the topics discussed, displeases or bothers his or her listeners.

2 Pinga or cachaça is a distilled spirit made from sugarcane.
} 


\section{Between roça and periphery}

In a lively bibliographic survey of works up to the 1970s, Moacir Palmeira and Alfredo W. B. de Almeida (1977) show how the idea of migration - and a wide assortment of derivatives: emigration, immigration, exodus and so on - became an important interpretative tool for thinking about, among many other demographic movements, the mobility of inhabitants of rural areas to urban centres. Works likes those of Eunice Durham (2004), based on research conducted in the 1960s and 7os, highlighted the connections between spatial mobility and the prospects of social advancement among rural migrants to the city of São Paulo, especially those settling in its outlying areas. On interviewing these migrants, the author noted a constant in their explanations for the quest to "improve their lives" in the state capital. She refers to the 'difficulties' of rural life, which she orders into four sets of allegations: "poverty and the lack of comfort; 'hard' work; the uncertainty of production; the impossibility of improvements" (Durham 2004: 170). While such explanations may still make sense for those seeking to "hunt a better life" (caçaruma vida melhor), as my interlocutors in the north of Minas Gerais would say, the transiting of people between the periphery and the rural world seems to be pushed into the background in favour of these fixed reference points.

The classic monograph The Hobo, by Nels Anderson (1967), originally published in 1923, was one of the first urban ethnographies to show how the activity of moving about is, in itself, a central element in the characterization of some social subjects. The sociologist's research was carried out in an area he calls Hobohemia, a locality to which the hobos gravitated, homeless and jobless wanderers, generally migrant workers originally from rural areas or small towns from the interior of the United States, who would transitorily find themselves in Chicago at the start of the twentieth century, even though they often found no work there. I would argue that the mobile way of life of the hobos, as expounded by Ulf Hannerz (1980: 34), albeit from a fixed viewpoint, the main stems located in Hobohemia, challenges the heuristic limits of the notion of migration insofar as it relativizes some of the ideas central to it, including the point of departure, point of arrival and direction.

Far from the large metropolises, a number of authors conducting ethnographic investigations in small municipalities, rural areas and riverside communities in the Cerrado region of Brazil, both in Goiás and Minas Gerais (Andriolli 2011; Benites 2015a; Carneiro 2010; Dainese 2011; Guedes 2013; Pereira 2011; Weitzman 2015), have recently expressed the same discomfort over the limitations that the ideas of departure, arrival and direction impose on the analysis of the movements of people and things explored in their research. In these works, we can observe the apprehension of "movement not only as displacements, flows, mobilities and circulations, but also as rhythms, tendencies, courses, speeds and sequences whose variations are irreducible to a single pattern" (Carneiro \& Dainese 2015: 146). Here movement is not reduced to scales, trajectories, coordinates or motivations given a priori: instead these works strive to apprehend the meanings constructed and mobilized in relations (between humans, but also between humans and non-humans) that generate a variety of movements. In this way, they aim to "ascertain, clarify and emphasize some of the specific forms through which movement emerges in analysis as an organizing principle of social dynamics" (ibid: 145).

Avoiding conceptualizing movement simply as the passage between a starting point and a destination, an approach that divests the phenomenon of any value in itself, André Dumans Guedes $(2013,2015)$ explores the distinct meanings possessed by the native idea of movement for inhabitants of the small municipality of Minaçu in the north of Goiás. For these people who witnessed the construction of three hydroelectric dams that ended any possibility of gold prospecting in the river running through the municipality, mobility is a value expressed in a rich vocabulary ('wandering,' 'travelling the road,' 'still,' 'dead,' 'animated,'

3 Caçar, "hunt", is a common expression in Minas Gerais to designate the activity of searching - sometimes uncertain in terms of the paths taken or end effects - undertaken by people with different objectives in mind. 
'agitated,' 'fever,' 'captivity,' and so on) that confers meaning to the practices and memories that weave the fabrics of their own lives. In the author's own words, movements, according to his interlocutors, can be conceived and experienced in the following acceptations:

a) movement as circulation, as spatial displacement, as travel or wandering, referring to the experiences of someone who, far from home, experiences the trecho [road] or the world; b) movement as agitation, animation, frenzy, fever; c) movement as effort or struggle, emblematic of the harsh and omnipresent reality of the impoverished who are always left chasing; d) movement as autonomy, associated with the freedom of someone in control of their own body, life and time; e) the latter aspect being closely associated with movement as evolution, progress, advancement, improvement of life, 'social mobility.' These axes can also be apprehended through the reference to that which, in each of them, problematizes or opposes the idea of movement: a) the lived experience of home and the family (Guedes 2012), or the calmness or rest experienced after a day of work and wandering; b) what is frozen, inanimate, dead, lifeless; or, on the other hand, calm or tranquil; c) being unable to walk with one's own legs; d) being captive or trapped; e) remaining still (Guedes 2015: 135).

The five axes listed by Guedes, based on the formulations and experiences of his interlocutors, provide a wealth of suggestions for contemplating other ethnographic contexts. Graziele Dainese (2011), for example, encountered the same connection between movement and animation/agitation evoked by Guedes. In Dainese's work there is an association between 'liking the roça' and the greater 'movement' existing in it. This connection derives from the fact that, in the Minas municipality studied by the author, a contrast is made between the 'desert' (absence of movement) of the town and the 'movement' of the rural world. The reason for the latter movement are the novenas and festivals held in celebration of Catholic saints at the weekends. This movement provides the chance to practice 'welcoming others,' feeding into the image of residents as a 'hospitable people' or 'welcoming people.' The animation and agitation of the festivals also extends to the so-called 'time of politics,' i.e. the electoral campaign periods when the disputing 'sides' expose the divisions, conflicts and social realignments existing in the region's small municipalities, as demonstrated in the works of Benites (2010, 2015b) Chaves (2003), Dainese (2011), and Palmeira \& Heredia (1995).

Returning the discussion to the transiting between rural areas and large metropolises, the work of Rodica Weitzman (2015) merits special attention. In a study of dietary and farming practices among Mineiros moving from Ubuporanga, a municipality in the east of Minas Gerais, to the Morro dos Prazeres and Escondidinho communities in Rio de Janeiro, the author shows how the activated memories, the practices of giving-receiving and requesting-offering, and their food classifications (Minas food, Rio food, strong and weak food, etc.) constitute intensive qualities within the emotional syntax and social circuits fomented in the rural-urban flux.

The quality of 'being Mineiro' evoked by the subjects studied by Weiztman refers back to their supposed origins: the roça. This is an important factor in social navigation within the Rio communities in question, specifically when it comes to reconstituting ties with kin and fellow Mineiros who have also settled there. Coming to Rio de Janeiro did not severe the bonds with their place of origin. Rather these ties are permanently actualized by the work of memory concerning life in the roças - nostalgic when referring to food, or painful when associated with the hard manual labour and hierarchical relations with bosses/ farmowners - and by the intense transit of people and things from the interior of Minas Gerais to the Rio capital. Relatives and friends visit frequently, when they are not swelling the labour networks of those who have already converged on the Morro dos Prazeres and Escondidinho communities. Some interlocutors visited Ubuporanga, especially during the Festa dos Ausentes, the Festival of the Absent, an annual event held for people from the municipality who have moved away to other cities. In this rural-urban circuit we 
can also observe a flow of goods, especially food items (cheeses, sausages, breads, seeds for home vegetable gardens, etc.). Also recreated in the Mineiro circle of these urban communities are various practices of small-scale farming, such as planting vegetable plots, a circuit of visits and reciprocity among conterrâneos (fellow Mineiros) and even the gathering of some medicinal herbs in the neighbouring Tijuca Forest. It is within the movement inscribed in the material and mnemonic shifts between the rural and urban worlds that the dichotomies of city-rural and past-present, though still reference points, "become diluted and blurred through lived practice" (Weitzman 2015: 26).

\section{Looking from Ribanceira and Gerais Velho}

Ribanceira and Gerais Velho are located in the São Francisco River Valley, in its Minas Gerais portion, and some of their residents maintain relations of kinship and friendship. Ribanceira is situated in the municipality of São Romão, on the left shore of the 'Velho Chico' (Old Francisco River) while Gerais Velho belongs to the municipality of Ubaí, which shares a border with São Romão, on the right shore of the same river. Ribanceira has around eighty-eight houses and Gerais Velho seventy. In both communities, a significant portion of the population mexe com roça, 'works the fields.' This expression designates the work dimension present in the everyday life of these interlocutors. The category mexer, shake, stir, functions here as an equivalent to the verb 'work,' but also frequently indicates the more general idea of dealing with something. In this sense, roça evokes the action of people working a terrain to produce some kind of foodstuff. The roça as a productive activity - felling forest, preparing the land, planting, harvesting and, in certain cases, processing what has been harvested, as in the case of the production of manioc flour; but also the breeding of livestock like cattle, pigs and chickens - mobilizes domestic groups and neighbours, producing and actualizing relations of affect and mutual consideration.

Social life in the two communities is characterized by an intense roaming in which the relocation to large urban centres is just one more movement in trajectories marked by mobility. In Ribanceira and Gerais Velho, the trips to and from home and the areas of cultivation and livestock breeding, the orchestration of work activities, their pauses for prosa, visits to relatives, friends and compadres, ${ }^{4}$ as well as the savouring of pinga, weave the fabric of social relations and the very meaning of life in the roça and on the waters of the São Francisco River. The personal trajectory of many of its inhabitants, especially the elderly, is marked by the mobility of relocating from one farm to another, working as agregados (tenant farmers) and caçando (hunting) a better life. The seasonal journeys to work in the coffee plantations in the Minas Triangle region, or in the region's charcoal kilns, also involve experiences of constant mobility. Additionally one kind of practice that pervades the life of these communities in regular cycles is also itinerant in fashion: the festivals. These events tend to be linked to a Catholic religious calendar (Nossa Senhora Aparecida, Bom Jesus, Santos Reis) mobilizing the choice of 'kings and queens' responsible for rituals of commensality in which food and drink are offered to members of the community, as well as processions of congado and caboclos leading the 'festival-goers' through the city, performances on horseback - called cavalhadas around the churches, and 'whirls' of groups of folias celebrating Santos Reis or Bom Jesus, depicted on flags that circulate through homes. In this context, I would also call attention to another notion of movement that emerges from these rural communities in relation to this type of event and that tends to suspend the work of the roça in order to initiate the festivals: agitation and animation, as in the ethnographies of Dainese (2011) and Guedes (2013).

4 For an analysis of compadrio relations (co-parenthood or Spanish compadrazgo) in the Latin American context, see Mintz \& Wolf (1950). 
These small and large displacements not only form part of the everyday life that I was able to record in fieldwork, they are part of the personal histories of the inhabitants of the localities in question. A world that oscillates, sometimes in tense form, between poles of fixedness and mobility, stability and instability, emerges in the studied life trajectories.

The temporary or definitive move to work in other localities is a phenomenon present in both communities. Leaving in search of better pay and regular work, many workers, especially young people, are mobilized by intermediaries with contacts in the city who call them to work in the harvesting a variety of crops in other regions of Minas Gerais and São Paulo. Others journey to large urban centres, especially São Paulo, Brasilia and Belo Horizonte. In this case, the men usually find employment in the civil construction sector and the women in domestic jobs. The majority have kin in Ribanceira and Gerais Velho to whom they send financial assistance, especially wives and children, when the latter are not among the kin and friends in the networks of employment allocation in which they are inserted.

In research carried out in the 1960 s and 7os with rural migrants to São Paulo, Durham (2004) had already noted the importance of families and groups of sociability from the community of origin in the dynamics of mobility in geographic and social spaces. In the author's words:

The spatial universe of the workers coming from traditional communities [...] is formed by places where their acquaintances were, or where people to whom they are related live. [...] [M]igration does not necessarily involve a dissolution of relations with the family or with the wider primary group (relatives, compadres, neighbours and friends) and possesses an eminently familiar character which, however, is not manifested in the relocation of the entire domestic group. On the contrary, spatial relocation is almost always undertaken by isolated individuals or by very small groups of two or three people. The familial aspect of the process is manifested in the frequent reconstitution, either total or partial, of the original family groups. Alongside relatives, conterrâneos [people from the same region] comprise another important reference group (Durham 2004: 189).

The cases observed by myself in Ribanceira and Gerais Velhos corroborate the author's analysis: the favelas of São Paulo's south zone, some on the border with Diadema like Americanópolis, are the preferred destination of residents in the studied localities, since this is where they find networks of social relations that function as their universe of reference and that maintain the connections between the community of origin and the city in which they chosen to settle. As in the study by Weitzman (2015), the histories of the definitive or temporary dislocations of some of my interlocutors and their families are also an axis via which the place of the roça is constituted through opposition to the city, specifically the large metropolis, given that the circulation of people between these places is frequent.

The inhabitants of Ribanceira and Gerais Velho who stayed temporarily in São Paulo spent from one to fifteen years in the state capital. Gilmar and Lindaura provide examples of a discourse widely disseminated in Gerais Velho concerning the relationship with time as an instigator of difference between the ways of life in the roça and the city. Gilmar, a young man of about thirty, is a compadre of Lindaura, owner of a small bar in Gerais Velho. Below I reproduce an excerpt of our conversation in Lindaura's bar. Gilmar lived in São Paulo for 12 years but "likes Gerais" and has no intention to leave there again, "only if necessary." A keen fan of Palmeiras, a leading São Paulo football club, Gilmar explains why he likes Gerais: "In Gerais you have freedom and time to do things. In São Paulo you're always chasing after time." Lindaura, for her part, associates time with slavery: 
In the past, you were a slave to the barons. Today the chains have passed from hands to feet. You're a slave to yourself, your bills, the work you have to do, your children. At least here in Gerais that's what it's like: you see Filu? [Filisberto, a neighbour who had just left the bar while we were talking.] He was on his way to take his cattle to the pasture, he stopped by here for a little bit of chat, drank his pinga, played some pool with you two [Gilmar and I] and is now on his way. Would you be able do that in São Paulo?

The control over time, combined with a sociability that is not submitted to heteronomic work, seems to delimit another dimension of the roça as a space and lifestyle that, despite the awareness of my interlocutors concerning its limitations in terms of access to certain material goods and the 'hard' manual labour involved, affirms an important aspect of how territorial belonging is conceived in these communities. While São Paulo is imagined as a place where "you're always chasing after time," this certainly includes the displacements from the periphery to the centre, as Agier (2015) describes. The sensation of a compression of space and time in the experience of life in the Sâo Paulo capital lend support to Marilyn Strathern's ideas concerning scale:

When distance is measured by time, getting there faster makes the globe seem smaller, and speed becomes a shorthand for space-time compression. [...] When what is being measured is independent of the means of measurement, we talk of the means of measurement as scales (Strathern 1999: 204-205).

In Ribanceira and Gerais Velho, time is configured - in many cases, though not exclusively - in cycles that are delimited by the adaptation to certain activities: the time of the rains and the drought, organizing farming and fishing activities; the time of politics, related to the period of open conflict that leads to social realignments around the sides disputing the elections; the time of festivals, constructing and actualizing relations of alliance and affect for the organization of the festivities, suspending quotidian work and instigating practices of intense enjoyment linked to Catholic worship, but also the profane dimensions associated with dancing, consuming alcohol, and so on.

In these modalities of experiencing time, the latter is measured by the activity that instigates it (the time of politics or the time of festivals) or by climatic alternations (dry periods and rainy periods). In other words, time is part of that which it designates and not a measure for other things (the working day, spatial mobility in the city, productivity, etc.). This is why "you're always chasing after time" in São Paulo. On the other hand, the experience circumscribed by the cycles of small-scale farming make clear that "it involves creating an appropriate time for the performance of particular activities deemed important by society" (Palmeira 2002:173). Although the relationship between appropriate time and the exercise of specific activities, with the consequent sensation of controlling time, is more apparent in the rural world than in the city, these temporal experiences can coexist, albeit often in conflicting form, in both social spaces. After all, as Bruno Latour (1993: 74) aptly reminds us: "time is not a general framework but a provisional result of the connection among entities."

The relationship with place is also constructed in the experience of transiting between the rural and the urban, especially when it comes to ownership of the land on which one lives. One of my interlocutors, Dona Benedita, told me that during the years when she lived in São Paulo, she worked as a volunteer on social projects run by a parish church close to the favela where she lived on the outskirts of the Santo Amaro district. At this time she knew a lot people, especially migrants from the northeast of the country, who were living in a vulnerable situation, jobless and incomeless. She asked many of them why they did not return to their home region. These people, most of rural origin, replied that they no longer had 'land': it had been sold either by the migrants themselves or their families. Benedita was saddened by this situation and observed that she and those she knew from Gerais Velho, despite living in São Paulo, still had their owns small plots of land to which they could one day return. At the same time, she knew that material needs 
meant that many of them had to sell their lands to pay back debts or to seek out better life opportunities in other localities. In her discourse, Benedita legitimized the process under way of obtaining official state recognition of the Gerais Velho territory as a quilombola community, which would transform land into a property for collective use that could not be sold, thereby safeguarding its ownership for future generations of the 'Povo do Gerais' [Gerais People].

\section{Searching for implications}

The Brazilian social sciences, Anthropology included, have conducted exhaustive studies of Brazil's urban peripheries as a destination for large numbers of people moving from rural areas or small town in the country's interior in search of better living conditions. Not infrequently, such relocations tend to be approached through the analytic frame of migration. As Palmeira and Almeida (1977) point out, the problem with the notion of migration is its emphasis on the points of departure and arrival of these processes. This does not mean that such emphases do not yield good investigative results, or robust data and precise analyses. In this article I have proposed an analytic shift that aims to attribute value to the movement of people and things in itself. In this way, we can obtain a clearer idea of the extensive and intensive qualities of movements:

On one hand, it concerns the quality of movement understood as a displacement in space, i.e. mobility in relation to specific spatial coordinates created by movement itself; on the other hand, we encounter it operating without any relation to travelled space, i.e. intensive, non-geographic movements. Yet these two forms of movement are not necessarily separate $[. .$.$] in general they are enmeshed and interdependent" (Carneiro \&$ Dainese 2015: 148).

By exploring movement in these terms, we are advocating an approach that applies equally to urban and rural worlds. It is not a question here of repeating the worn out simplifications of the invasion of rural areas by urban practices. This idea seems to derive from the idea of migration itself, which fixes rural and urban localities in dichotomous fashion and prevents us from perceiving the more subtle processes involved in the constitution of these two social spaces. After all,

[...] the notions of 'rural' and 'urban,' as well as that of 'rurality' and the duality intrinsic to them, are social representations that express distinct worldviews and values determined by the symbolic universe to which they refer, thus making them subject to re-elaborations and diverse appropriations. Members of the Brazilian agrarian elite resort to practices and habits taken to be 'rural' but which, giving new meaning in other cultural contexts, serve the aim of showing and at the same time instituting their modern face. Meanwhile the Brazilian 'neo-rurals,' motivated by values proper to the old rural world (self-determination, contact with nature, tranquillity, simplification of social relations), reproduce productive and technological urban values at a rational level (Carneiro 1998: 60-61).

While the roça is central to the identity of the inhabitants of Ribanceira and Gerais Velho, such communities have also become consolidated as a key reference point for those moving to live in São Paulo for many years. The history of the inhabitants of Gerais Velho as a history of black people in search of autonomy is revealed, for example, in the dialogue that unfolded in Lindaura's bar concerning Filu's 'path.' The experience of freedom constructed on a daily basis by these inhabitants is found among few

5 Povo, 'People', is a regional term used to designate a set of persons linked by at least one of the following relations, which may also be combined, depending on the case at hand: descent and/or alliance, neighbours, or identification with a locality or institution. In the case described here it refers to the inhabitants of a locality (Gerais Velho) who also, though, maintain relations as neighbours and kin. 
people, it is true. However, such an experience is replicated in the festivals associated with the Catholic religious calendar, when they draw back to the community those we left the area in search of better life opportunities.

While the rural-urban flow contains exchanges that enable the absorption of technological and musical novelties, like the latest releases by forro and rap bands cited in the preamble to the article, in terms of the circulation of food produce (Weitzman 2015), the festivals in the rural communities provide ideal ritual moments for re-encounters and for material and affective exchanges.

The idea of the periphery as a primary locus of poverty, urban violence and sociospatial segregation is not given any special emphasis in the work of memory of my interlocutors, save for remarks concerning rap lyrics and their evocation of the difficulties of life in the metropolis. Instead, the idea of movement as "chasing after time" in São Paulo is mobilized much more as a contrast to the tranquillity and autonomy of life in the roça, whose movement, in the sense of animation and agitation (Dainese 2011; Guedes 2015), emerges in the cycles of the religious festivals with their processions, whirling folia and forró dances. While in the work of Weitzman (2015), the city is evoked as a less heteronomic place of work, given the onerous patronal relations found in the rural world, in Gerais Velho and Ribanceira people say that the farming work is more under their control than in the city. In both cases, the discomfort seems to centre on the relations intrinsic to wage labour. For the residents of Morro dos Prazeres, this involves the relation between the farmer and his tenants. For the inhabitants of Gerais Velho and Ribanceira, who hold ownerships of their territories, the boss-employee relation is located in the city and in seasonal activities like harvesting crops in other municipalities or working at the charcoal burners in the region, neither of which are viewed as roça work.

The native idea of belonging seems to be associated with an idea of movement in contrast to the notion of fixity, even though the land on which one produces and lives is an important reference point. This movement is constituted through the very experience of being in transit: from house to work, from work to the bar, from Gerais and Ribanceira to neighbouring communities or to the São Paulo periphery, from house to house in the folia celebrations, and so forth. The very language of northern Minas, through the use of categories like mexer and caçar cited earlier, are signals of this fact. It is within these movements that the social bonds determining the meaning of belonging to these localities are produced and reinforced. In Ana Carneiro's ethnography, the journey between places is summarized in a saying frequently repeated by residents from Vão dos Buracos: "who doesn't walk, doesn't know" (Carneiro 2010: 277). Perhaps we could take this saying as encapsulating a local form of learning with strong echoes found in Tim Ingold's thought:

...lives are led not inside places but through, around, to and from them, from and to places elsewhere [...]

Places, then, are like knots, and the threads from which they are tied are lines of wayfaring [...] Places, in short, are delineated by movement, not by the outer limits to movement (Ingold 2011: 148-149).

What we can extract from all this is the idea that the spatial conquest associated with displacement, as described by Agier (2015: 491) in his characterization of the city, needs to be conceived beyond the heuristic limits of the urban world. Movements also need to be apprehended in terms of the autonomy and freedom that they imply for people who settle in the rural world or in the city, as well as for those who continually transit between them. Paying attention to both the extensive and intensive qualities of the movements of people and things can provide a rich source of material for developing a more complex understanding of the relations between rural and urban without running the risks of freezing one of these poles. 
Recently some social scientists have claimed the emergence of a "mobility turn" or even of a "new mobilities paradigm" (Sheller \& Urry 2006, Creswell 2006). ${ }^{6}$ This new approach encompasses a broad set of research produced in areas such as anthropology, sociology, geography, cultural studies, science studies and technology. These investigations are characterized, on one hand, by the critique of 'static' social science and, on the other, by an apprehension of the new and multiple mobilities of humans and non-humans produced by the sociotechnical transformations of the contemporary world. In this scenario, "[i]ssues of movement, of too little movement or too much, or of the wrong sort or at the wrong time, are central to many lives and many organisations" (Sheller \& Urry 2006: 208).

While this theoretical and methodological turn in the field of the social sciences has contributed to a more complex and refined understanding of the movements of people and things overlooked or underestimated by static or sedentary views of social life, some caution is needed in evoking the idea. It can easily convert into a replication of the vices of the rural-urban opposition by reducing the dynamic of mobilities in these rural areas solely to by-products of the flows of modern capitalist liquidity gestated in the cities.

Classic works like that of Pierson (1972: 39) had already noted in the 1950s "a considerable demographic movement, namely: inside, to inside, from inside to outside, and through the community" in diverse settlements along the São Francisco River. Pierson (1972) and Neves (2011) associated the wanderings of the inhabitants of the São Francisco Valley with a supposed cultural disposition inherited both from the many indigenous populations who historically inhabited the territories along the river and from the bandeirantes who later explored the region. Irrespective of this allusion, the mobility of these populations can be conceived in terms of the distinct practices of displacement that make up a swidden-based and riverine sociality. Although Gerais Velho and Ribanceira are not immune from the technological and economic transformations of the globalized world, the circulations and movements of persons and things appear to be rooted in the very personal history of their members and, consequently, in the long-term dynamic of social life of these communities. Above all, the threads that weave the fabric of life in both communities seem to be indissociable from the respective wanderings of their members. Recognizing this dynamic does not mean ignoring their connections to broader and more deterritoralized processes, but rather ceasing to attribute any precedence or exclusivity to the association of the city with movement. Instead, this comprehension can set in motion our own suppositions concerning the city and the periphery.

\section{Translated by David Rodgers}

Received: January 25, 2017; Approved: July 08, 2017

\footnotetext{
6 Tim Creswell formulates a conceptual distinction between movement and mobility: "The movements of people (and things) all over the world and at all scales are, after all, full of meaning. They are also products and producers of power. I want to make an analytical distinction here between movement and mobility. For the purposes of my argument, let us say that movement can be thought of as abstracted mobility (mobility abstracted from contexts of power). Movement, therefore, describes the idea of an act of displacement that allows people to move between locations (usually given as point A and point B in abstract and positivist discussions of migration). Movement is the general fact of displacement before the type, strategies, and social implications of that movement are considered."(Creswell 2006: 2-3).

7 Bandeirantes were the organizers of private expeditions called bandeiras (flag), which explored the inland territories of Brazil between the seventeenth century and the early years of the eighteenth century. These expeditions used to carry a flag to identify them. The main objective of the bandeirantes was to find gold, precious stones, and to imprison indigenous people who would be sold as slaves.
} 


\section{References}

AGIER, Michel. 2015. “Do direito à cidade ao fazer-cidade: o antropólogo, a margem e o centro”. Mana. Estudos de Antropologia Social, 21(3): 483-498.

ANDERSON, Nels. 1967. The Hobo: the sociology of homeless man. Chicago: Chicago University Press.

ANDRIOLLI, Carmen Sílvia. 2011. Sob as vestes do Sertão Veredas, o Gerais: "mexer com criação" no sertão do Ibama. PhD thesis, Programa de Pós-Graduação em Ciências Sociais, Unicamp, Campinas.

BENITES, Luiz Felipe Rocha. 2010. Olhando da Ribanceira: Perspectivas de Influência e Vulnerabilidade no Vale do Alto-Médio São Francisco. PhD thesis, Museu Nacional, UFRJ, Rio de Janeiro. . 2015a. "Mexendo com a roça: trabalho e movimento no Sertão Mineiro". Ruris, 9 (1): 39-61. . 2015b. "Da 'consideração' e da acusação: notas etnográficas sobre reputação, fofocas e rumores na política”. In: John Comerford; Ana Carneiro; Graziele Dainese (eds.), Giros etnográficos em Minas Gerais: casa, comida, prosa, festa, política, briga e o diabo. Rio de Janeiro: 7 Letras/FAPERJ. pp. 65-92.

CARNEIRO, Ana. 2010. O "Povo" Parente dos Buracos: mexida de prosa e cozinha no Cerrado Mineiro. PhD thesis, Museu Nacional, UFRJ, Rio de Janeiro.

.; DAINESE, Graziele. 2015. "Notas sobre diferenças e diferenciações etnográficas do movimento". Ruris, 9(1): 143-166.

CARNEIRO, Maria José. 1998. "Ruralidade: novas identidades em construção". Estudos Sociedade e Agricultura, 11: $53-75$.

CHAVES, Christine Alencar. 2003. Festas da política: uma etnografia da modernidade no sertão (Buriti-MG). Rio de Janeiro: Relume-Dumará.

CRESSWELL, Tim. 2006. On the move: mobility in the modern west world. New York: Routledge.

DAINESE, Graziele. 2011. Chegar ao cerrado mineiro: hospitalidade, política e paixões. Tese de Doutorado. Museu Nacional, UFRJ, Rio de Janeiro.

DURHAM, Eunice. 2004. "Migrantes rurais”. In: A dinâmica da cultura. São Paulo: Cosac \& Naify. pp. 181-201.

GUEDES, André Dumans. 2013. O trecho, as mães e os papéis: etnografia de movimentos e durações no norte de Goiás. São Paulo: Garamond.

. 2015. "Andança, agitação, luta, autonomia, evolução: sentidos do movimento e da mobilidade". Ruris, 9(1): 111-141.

HANNERZ, Ulf. 1980. Exploring the city: inquiries toward an urban anthropology. New York: Columbia University Press.

INGOLD, Tim. 2011. Being alive: essays on movement, knowledge and description. London: Routledge.

LATOUR, Bruno. 1993. We have never been modern. Cambridge, Massachucetts: Harvard University Press.

MINTZ, Sidney; WOLF, Eric. 1950. "An analysis of ritual co-parenthood (compadrazgo). Southwestern Journal of Anthropology, 6(4):341-368.

NEVES, Zanoni. 2011. Navegantes da integração: os remeiros dos rio São Francisco. 2aed. Belo Horizonte: Ed. UFMG.

PALMEIRA, Moacir. 2002. "Política e tempo: nota exploratória". In: Marisa Peirano (ed.), O dito e o feito: ensaios de antropologia dos rituais. Rio de Janeiro: Relume-Dumará. pp 171-177. . ; ALMEIDA, Alfredo W. B. 1977. "A invenção da migração". Projeto emprego e mudança socioeconômica no Nordeste (Relatório de Pesquisa). Rio de Janeiro, Museu Nacional/UFRJ. Mimeo. .; HEREDIA, Beatriz. 1995. "Os comícios e a política de facções”. Anuário Antropológico, 94: 31-94.

PEREIRA, Luzimar Paulo. 2011. Os giros do sagrado: um estudo etnográfico sobre as folias em Urucuia, MG. Rio de Janeiro: 7 Letras.

PIERSON, Donald. 1972. O homem do Vale do São Francisco. Tomo II. Rio de Janeiro: Ministério do Interior| Superintendência do Vale do São Francisco. 
SHELLER, Mimi; URRY, John. 2006. “The new mobilities paradigm”. Environment and Planning, 38: 207-226. STRATHERN, Marilyn. 1999. "Puzzle of scales". In: Property, substance and effect: anthropological essays on persons and things. London: The Athlone Press. pp. 204-228.

WEITZMAN, Rodica. 2015. "Mineiros em movimento: flutuação dos significados das práticas alimentares e agrícolas a partir do fluxo rural-urbano". Sociedade e Cultura, 18(1): 13-28.

Luiz Felipe Rocha Benites

Federal Rural University of Rio de Janeiro - Multidisciplinary Institute - Department of History, Nova Iguaçu/RJ, Brazil.

E-mail: felipebenites74@gmail.com 